\title{
Tectono-Metamorphic evolution of the Grenville-aged Jahazpur shear zone, in Northwest India
}

\author{
S.GUPTA,${ }^{1 *}$, N.ALFIMOVA ${ }^{2}$,L. SAHA ${ }^{1}$, \\ A.PrAKASH ${ }^{1,3}$ AND E.BOGOMOLOV ${ }^{4}$ \\ ${ }^{1}$ Department of Earth Sciences, Indian Institute of Technology \\ Roorkee(*shikhasssom@gmail.com,;saha.lopamudra@gmail.com) \\ Institute of Earth Sciences, Saint Petersburg State University \\ Russia \\ 3 Center for Tectonophysics, Department of Geology and Geophysics, \\ MS 3115,Texas A\&M University \\ 4Institute of Precambrian geology and geochronology RAS, Saint- \\ Petersburg, Russia
}

In this study for the first time we present detailed petrological and geochronological data from with well-constrained P-T history from the garnetiferous mica schists of the Jahazpur Shear Zone (JSZ). Our study indicates that the western belt of the JSZ at the contact of the $\sim 1.7 \mathrm{Ga}$ migmatites of the Bhilwara Belt comprise on interlayered sequences of amphibolite, quartzite and garnet-mica schists. The shear fabric in the garnetiferous mica schist is defined by ENEWSW striking shear fabric defined by muscovite, biotite, quartz. Spiral inclusion trails of quartz within the garnet porphyroblasts imply syntectonic growth of the porphyroblasts during the formation of the shear fabric. The peak P-T conditions of garnet formation within the rock is constrained between $5-6 \mathrm{kbar}, 500-550^{\circ} \mathrm{C}$.

$\mathrm{Sm}-\mathrm{Nd}$ isotopic analyses conducted from the whole rock bulk compositions of the amphibolite and the garnet mica schist yield TDM model ages of 3001 and $3070 \mathrm{Ma}$ respectively. On the contrary the isochrons constrained from the whole rock and the metamorphic mineral separates yield ages $979 \mathrm{Ma}$ from the amphibolite and $955 \mathrm{Ma}$ from the mica schist. We therefore conclude that the Jahazpur Group of rocks from the western belt represent a Mesoarchaean volcano-sedimentary sequence $\left(\begin{array}{lll}\sim 3.0 & \mathrm{Ga}\end{array}\right)$ that were metamorphosed under mid-crustal lower amphibolite facies conditions during formation of the JSZ between $\sim 980-955$ Ma. 